\title{
WNT2 Gene
}

National Cancer Institute

\section{Source}

National Cancer Institute. WNT2 Gene. NCI Thesaurus. Code C18353.

This gene plays a role in signal transduction and intercellular communication. It is involved

in the mediation of cell behavior and fate during vertebrate development. 